\title{
Comparison of Simulated Drift Rates of Common ALS-Inhibiting Rice Herbicides to Florpyrauxifen-Benzyl on Soybean
}

\author{
Lauren M. Schwartz-Lazaro, ${ }^{1}$ M. Ryan Miller, ${ }^{2}$ Jason K. Norsworthy, ${ }^{2}$ and Robert C. Scott ${ }^{3}$ \\ ${ }^{1}$ School of Plant, Environmental, and Soil Sciences, Louisiana State University AgCenter, Baton Rouge, LA 70803, USA \\ ${ }^{2}$ Department of Crop, Soil, and Environmental Sciences, University of Arkansas, Fayetteville, AR 72704, USA \\ ${ }^{3}$ Department of Crop, Soil, and Environmental Sciences, University of Arkansas, Lonoke, AR 72086, USA \\ Correspondence should be addressed to Lauren M. Schwartz-Lazaro; 1lazaro@agcenter.lsu.edu
}

Received 29 June 2017; Accepted 28 September 2017; Published 22 October 2017

Academic Editor: Kassim Al-Khatib

Copyright (c) 2017 Lauren M. Schwartz-Lazaro et al. This is an open access article distributed under the Creative Commons Attribution License, which permits unrestricted use, distribution, and reproduction in any medium, provided the original work is properly cited.

\begin{abstract}
Acetolactate synthase- (ALS-) herbicides are among the most commonly used sites of action (SOA) in rice production. Many herbicides used in rice can cause carryover to soybean, which is commonly grown near to or rotated with rice. Florpyrauxifen-benzyl (Rinskor ${ }^{\mathrm{TM}}$ Active) brings an alternative SOA to rice production. The objective of this study was to compare the effects of simulated drift rates of florpyrauxifen-benzyl to commonly used ALS-inhibiting rice herbicides on soybean. A field study was conducted at two locations examining five ALS-inhibiting rice herbicides as well as florpyrauxifen-benzyl at a 1/20x and 1/80x simulated drift rate. Crop injury, height, and yield were evaluated at 14, 21, and 35 days after treatment (DAT). Florpyrauxifen-benzyl and bispyribac showed high injury levels at both drift rates. At 35 DAT florpyrauxifen-benzyl caused $76 \%$ and $17 \%$ visible damage to soybean whereas bispyribac caused 35 and $9 \%$ injury at 1/20x and 1/80x, respectively. These treatments resulted in a reduction in soybean height and yield. Although this alternative SOA herbicide in rice may be effective for weed control, our research demonstrates it to be injurious to soybean at both drift rates tested. Thus, proper precautions should be taken to avoid injury by ensuring that the label is followed.
\end{abstract}

\section{Introduction}

Drift from auxin-type herbicides is currently a major concern within the agricultural community [1]. Drift can be categorized into either physical or vapor drift. Physical, or particle, drift occurs at the time of application and is influenced by wind speed [2]. Additionally, improper application speed, height above target, and nozzle selection can also contribute to the occurrence of physical drift [3]. When examining aerially applied herbicides, height above the target would be the primary factor contributing to drift. Vapor drift, conversely, is primarily a function of volatilization that takes place after spray particles reach their intended site. This form of drift can be influenced by various abiotic factors, such as temperature and relative humidity $[4,5]$. Increased temperature and low humidity tend to intensify the risk for volatility to occur by increasing the amount of atmospheric space for evaporation to take place [4]. Auxin-type herbicide residues, such as 2,4$\mathrm{D}$ and dicamba, are known to be difficult to clean from spray equipment, and small amounts of these compounds could be inadvertently applied to susceptible crops if the same equipment was subsequently used to treat non-dicamba or non-2,4-D-resistant crops [6]. Finally, in regions where 2,4-D or dicamba are used frequently and over large areas, herbicide residues can accumulate in the atmosphere and return to fields as precipitation at concentrations high enough to cause injury to susceptible crops $[7,8]$.

In the mid-southern United States (US), soybean is frequently grown in close proximity to rice or rotated with rice [9]. The overreliance on herbicides with the same site of action (SOA), such as acetolactate synthase- (ALS-) inhibitors, has led to many weed species evolving resistance 
to these herbicides [10]. For example, in the US, there are ten reported weeds, in rice, that are resistant to ALSinhibitors [11]. The continued evolution of herbicide-resistant weeds is only increasing further with more cases being reported. Therefore, a new herbicide SOA is needed in rice production that will limit not only the frequency of resistance in weed species, but also any injury to soybean. The introduction of florpyrauxifen-benzyl (Dow AgroSciences LLC, Indianapolis, IN) will be a new SOA for weed control in rice. Florpyrauxifen-benzyl (Rinskor Active) is a new active ingredient in the arylpicolinate herbicide family and represents the second herbicide (the other one being halauxifenmethyl) in the new structural class of synthetic auxins having a unique receptor binding activity $[12,13]$. Members of this family exhibit distinctive characteristics for synthetic auxins by providing broad-spectrum postemergence activity on broadleaf, grass, and sedge species at low use rates. The addition of the compound to the US rice marketplace will provide an alternative SOA, thereby providing effective control of propanil-, quinclorac-, clomazone-, and ALS-resistant barnyardgrass, ALS-resistant rice flatsedge, smallflower umbrella sedge, yellow nutsedge, and other troublesome weeds in rice cropping system [12]. Furthermore, previous research supports a relatively short ( $\leq 60$ days) plant-back interval for soybean after florpyrauxifen-benzyl application compared to other herbicides commonly used in rice [14].

There is little research, however, on risk for injury to soybean caused by florpyrauxifen-benzyl drift [15]. Soybean, cotton (Gossypium hirsutum L.), and grain sorghum (Sorghum bicolor) are among the crop species most susceptible to synthetic auxin herbicides, such as dicamba, 2,4-D, and florpyrauxifen-benzyl. Previous research has reported numerous consequences of dicamba drift onto non-dicambaresistant soybean, such as reduced growth, fewer seeds per pod, lower seed quality, maturity delays, and pod malformation [16-20]. Symptomology can vary from chlorosis of the terminal buds, cupping or crinkling of canopy leaves, and leaf or stem epinasty. Higher rates can even result in stem cracking, terminal death, or plant death $[17,21,22]$. The risk of crop injury and potential yield loss will perhaps be greatest to growers who choose not to be aware of crops in surrounding fields or who choose not to use resistant varieties in regions where these varieties and associated herbicide programs are widely adopted by neighboring farmers [23]. Thus, the objective of this study was to determine the effects of various drift rates of florpyrauxifen-benzyl relative to commonly used ALS-inhibiting herbicides on soybean.

\section{Methods}

A field experiment was conducted in 2016 at the Arkansas Agricultural Research and Extension Station (AAES) in Fayetteville, Arkansas, and at the Rice Research and Extension Center (RREC) near Stuttgart, Arkansas. Each experimental plot contained four rows spaced $91 \mathrm{~cm}$ apart resulting in an overall plot size of $3.6 \mathrm{~m}$ wide by $6 \mathrm{~m}$ long. At both sites, a non-ALS tolerant variety was planted. Pioneer 95L01 was planted on May 5 and May 11 at AAES and PTRS, respectively. Soybean was planted at a $2-\mathrm{cm}$ depth at
120,000 seed ha ${ }^{-1}$ using a tractor-mounted John Deere 7200 MaxEmerge planter (John Deere Seeding Group, Moline, IL). Plots were kept weed-free utilizing labeled herbicides and occasional hand weeding. All herbicide treatments were applied at the V3 growth stage to the two center rows with a $\mathrm{CO}_{2}$-pressurized backpack sprayer fitted with 110015 AIXR nozzles (Teejet Technologies, Springfield, IL) calibrated to deliver $140 \mathrm{~L} \mathrm{ha}^{-1}$ at $4.8 \mathrm{~km} \mathrm{hr}^{-1}$.

The experiment was arranged as a randomized complete block design with a two-factor factorial treatment structure and four replications. The first factor was herbicide treatment. Treatments consisted of five ALS-inhibiting herbicides: bispyribac (Regiment; Valent USA Corporation, Walnut Creek, CA) with a 1x rate of $27 \mathrm{~g}$ a ha $^{-1}$, penoxsulam $\left(\right.$ Grasp $^{\circledR}$, Dow AgroSciences LLC, Indianapolis, IN) with a $1 \mathrm{x}$ rate of $35 \mathrm{~g}$ ai ha ${ }^{-1}$, halosulfuron (Permit; Gowan Company, Yuma, AZ) with a $1 \mathrm{x}$ rate of $40 \mathrm{~g} \mathrm{ai} \mathrm{ha}^{-1}$, orthosulfamuron (Strada, Nichino America Inc., Wilmington, DE) with a 1x rate of $69 \mathrm{~g}$ ai $\mathrm{ha}^{-1}$, and imazosulfuron (League, Valent USA Corporation, Walnut Creek, CA) with a $1 \mathrm{x}$ rate of $336 \mathrm{~g}$ ai ha ${ }^{-1}$, as well as florpyrauxifen-benzyl (Rinskor Active) with a $1 \mathrm{x}$ rate of $30 \mathrm{~g}$ ai ha $^{-1}$, and a nontreated control. The second factor was simulated drift rates. Each herbicide was applied at two simulated drift rates of $1 / 20 \mathrm{x}$ and $1 / 80 \mathrm{x}$ with florpyrauxifenbenzyl, bispyribac, and penoxsulam containing a $1 \% \mathrm{v} / \mathrm{v}$ of methylated seed oil (MSO), halosulfuron containing $1 \% \mathrm{v} / \mathrm{v}$ crop oil concentrate (COC), and orthosulfamuron and imazosulfuron containing $0.25 \% \mathrm{v} / \mathrm{v}$ nonionic surfactant (NIS). The simulated drift rates were made using serial dilutions from a $1 \mathrm{x}$ stock solution of each herbicide.

Data collection included estimates of visible injury on a scale of 0 to $100 \%$, with $0 \%$ representing no injury and $100 \%$ representing complete crop death at 14, 21, and 35 days after treatment (DAT). In addition, crop height to the terminal at each rating was measured. Grain yield was also collected by harvesting the two treated rows and correcting for moisture at $13 \%$. Site, herbicide treatments, and drift rates were treated as fixed factors and replications were treated as random. Data were subjected to analysis of variance (ANOVA) in JMP Pro 12 (JMP Pro 12, SAS Institute Inc., Cary, NC). Where the ANOVA indicated significance, means were separated using Fisher's protected least significant difference test $(P=0.05)$.

\section{Results and Discussion}

There was no significant effect or interaction with site; thus data were pooled over sites. There was a significant interaction $(P=0.02)$ between drift rate and herbicide treatment for all evaluations (Table 1). All treatments resulted in injury 14 DAT, with the $1 / 20 \mathrm{x}$ drift rate having higher injury than the $1 / 80 \mathrm{x}$ drift rate, except for halosulfuron. Regardless of the drift rate, florpyrauxifen-benzyl was more injurious to the soybean than the other herbicides within a drift rate. For example, injury caused by florpyrauxifen-benzyl at the $1 / 20 \mathrm{x}$ and $1 / 80 \mathrm{x}$ drift rates was 71 and $31 \%$ at $21 \mathrm{DAT}$ and 76 and $17 \%$ at $35 \mathrm{DAT}$, respectively. Likewise, soybean height was reduced by both rates of florpyrauxifen-benzyl at 14 and 21 DAT. Bispyribac also produced a higher level of crop injury than the 


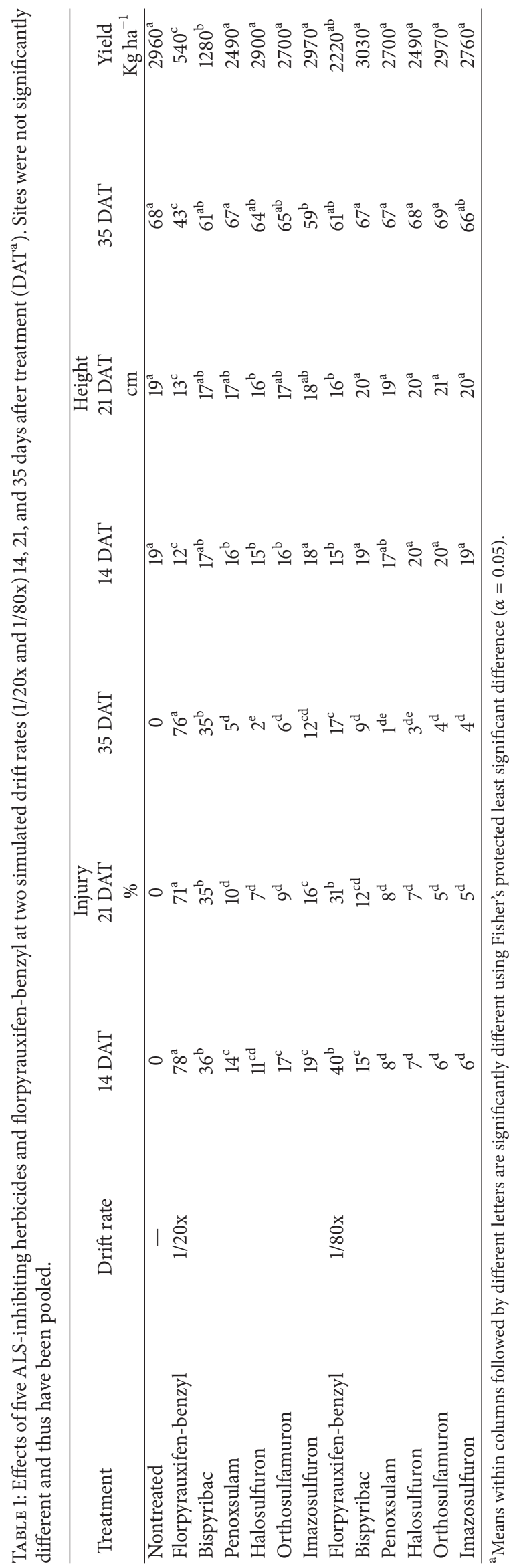


other ALS-inhibiting herbicides at 21 and 35 DAT at the 1/20x drift rates (35\% injury), albeit lower than florpyrauxifenbenzyl. Most ALS-inhibiting herbicides applied at a 1/20x rate caused initial stunting of soybean at 14 DAT, but by 35 DAT, most had recovered to the point of being comparable in height to the nontreated control.

The high degree of crop injury and stunting had a significant effect on yield. The nontreated control yielded $2960 \mathrm{~kg} \mathrm{ha}^{-1}$ whereas soybean treated with florpyrauxifenbenzyl at a $1 / 20 \mathrm{x}$ and $1 / 80 \mathrm{x}$ rate yielded 540 and $2,220 \mathrm{~kg} \mathrm{ha}^{-1}$ (82 and 25\% yield loss), whereas plants treated with bispyribac, the most injurious ALS herbicide, had yields of 1280 and $3030 \mathrm{~kg} \mathrm{ha}^{-1}$ (57\% and $0 \%$ yield loss) at comparable drift rates. The other four ALS-inhibiting herbicides did not differ in yield from the nontreated control at either drift rate. Although florpyrauxifen-benzyl may be highly effective in weed control [24], this new SOA will need to be used with caution and following label application recommendations when soybean is in close proximity to rice as there appears to be slightly greater risk of crop injury than with currently used ALS rice herbicides.

Although florpyrauxifen-benzyl will provide midsouthern rice growers with an alternative herbicide SOA that is capable of achieving a high level of weed control [24], it will be injurious to soybean at a 1/80x and 1/20x drift rate. Furthermore, regardless of drift rates, soybean yield was reduced in comparison to the nontreated control. Caution should be exercised when applying florpyrauxifen-benzyl when soybean is in close proximity to rice.

\section{Conclusions}

This study compared the effects of simulated drift rates of florpyrauxifen-benzyl to commonly used ALS-inhibiting rice herbicides on soybean and found that at $1 / 20$ and $1 / 80$ of the $1 \mathrm{x}$ rate, florpyrauxifen-benzyl caused a significant increase in crop injury and crop height and yield reduction. Previous research has documented many consequences associated with auxin herbicide drift onto soybean, such as fewer seeds per pod, lower seed quality, pod malformation, and reduced yield [16-18] as well as reduced growth when exposed to drift rates of auxin herbicides, all of which were documented in this study. New herbicides are needed, however, to enhance SOA diversity, which would lessen the risks of herbicideresistance evolution [25] and could improve weed control. However, growers should exercise caution and strictly follow label recommendations when applying florpyrauxifen-benzyl to a rice field where soybean is adjacent. In addition, soybean cultivars expressing tolerance to dicamba or 2,4-D will not protect against off-target movement of this herbicide (trademark of The Dow Chemical Company ("Dow") or an affiliated company of Dow).

\section{Conflicts of Interest}

The authors declare that there are no conflicts of interest regarding the publication of this paper.

\section{Acknowledgments}

This research was funded by the Arkansas Rice Research and Promotion Board, Dow AgroSciences, and the University of Arkansas Division of Agriculture.

\section{References}

[1] D. S. Riar, J. K. Norsworthy, L. E. Steckel, D. O. Stephenson IV, T. W. Eubank, and R. C. Scott, "Assessment of weed management practices and problem weeds in the Midsouth United States Soybean: A consultant's perspective," Weed Technology, vol. 27, no. 3, pp. 612-622, 2013.

[2] J. Maybank, K. Yoshida, and R. Grover, "Spray drift from agricultural pesticide applications," Journal of the Air Pollution Control Association, vol. 28, no. 10, pp. 1009-1014, 1978.

[3] N. Yarpuz-Bozdogan, "Drift of pesticides," Encyclopedia of Pest Mngmt, http://www.tandfonline.com/doi/abs/10.1081/E-EPM120009991\#.VSP_7rB8OM8.

[4] T. C. Mueller, D. R. Wright, and K. M. Remund, "Effect of formulation and application time of day on detecting dicamba in the air under field conditions," Weed Science, vol. 61, no. 4, pp. 586-593, 2013.

[5] J. F. Egan and D. A. Mortensen, "Quantifying vapor drift of dicamba herbicides applied to soybean," Environmental Toxicology and Chemistry, vol. 31, no. 5, pp. 1023-1031, 2012.

[6] C. Boerboom, "Field case studies of dicamba movement to soybeans," in Proceedings of the Wisconsin Fertilizer, Aglime, and Pest Management Conference, p. 5, 2004.

[7] B. D. Hill, K. N. Harker, P. Hasselback, J. R. Moyer, D. J. Inaba, and S. D. Byers, "Phenoxy herbicides in Alberta rainfall: Potential effects on sensitive crops," Canadian Journal of Plant Science, vol. 82, no. 2, pp. 481-484, 2002.

[8] L. Tuduri, T. Harner, P. Blanchard et al., "A review of currently used pesticides (CUPs) in Canadian air and precipitation. Part 2: Regional information and perspectives," Atmospheric Environment, vol. 40, no. 9, pp. 1579-1589, 2006.

[9] C. E. Wilson Jr., S. K. Runsick, and R. Mazzanti, "Trends in Arkansas rice production," in Arkansas Agriculture Experiment Station Research, vol. 581 of B.R. Wells Rice Research Studies, pp. $11-21,2010$.

[10] J. K. Norsworthy, J. Bond, and R. C. Scott, "Weed management practices and needs in Arkansas and Mississippi rice," Weed Technology, vol. 27, no. 3, pp. 623-630, 2013.

[11] Heap, I . The international survey of herbicide resistant weeds. Available from: http://www.weedscience.org, 2017.

[12] J. B. Epp, A. L. Alexander, T. W. Balko et al., "The discovery of Arylex $^{\mathrm{TM}}$ active and Rinskor ${ }^{\mathrm{TM}}$ active: Two novel auxin herbicides," Bioorganic \& Medicinal Chemistry, vol. 24, no. 3, pp. 362371, 2016.

[13] M. R. Weimer, C. Yerkes, P. Schmitzer, and R. K. Mann, Introduction to a new arylpicolinate herbicide from Dow AgroSciences with utility in rice and other crops, Weed Sci Soc Amer, Lexington, Kentucky, USA, 2015.

[14] M. R. Miller, J. K. Norsworthy, M. R. Weimer, R. Huang, Z. Lancaster, and S. Martin, Environmental fate of Rinskor ${ }^{\mathrm{TM}}$ active: field dissipation and replant interval for soybean, Weed Sci Soc Amer, San Juan, Puerto Rico, USA, 2016a.

[15] M. R. Miller, J. K. Norsworthy, M. R. Weimer, M. L. Young, J. K. Green, and G. T. Jones, Drift potential of Rinskor ${ }^{T M}$ Active: assessment of off-target movement to soybean, Weed Sci Soc Amer, San Juan, Puerto Rico, USA, 2016b. 
[16] D. E. Auch and W. E. Arnold, "Dicamba use and injury on soybeans (Glycine max) in South Dakota," Weed Science, vol. 26, pp. 471-475, 1978.

[17] J. L. Griffin, M. J. Bauerle, D. O. Stephenson III, D. K. Miller, and J. M. Boudreaux, "Soybean response to dicamba applied at vegetative and reproductive growth stages," Weed Technology, vol. 27, no. 4, pp. 696-703, 2013.

[18] K. B. Kelley, L. M. Wax, A. G. Hager, and D. E. Riechers, "Soybean response to plant growth regulator herbicides is affected by other postemergence herbicides," Weed Science, vol. 53, no. 1, pp. 101-112, 2005.

[19] L. M. Wax, L. A. Knuth, and F. W. Slife, "Response of soybeans to 2,4-D, dicamba and picloram," Weed Science, vol. 17, pp. 388393, 1969.

[20] J. D. Weidenhamer, G. B. Triplett, and F. E. Sobotka, "Dicamba Injury to Soybean," Agronomy Journal, vol. 81, no. 4, pp. 637643, 1989.

[21] C. B. Solomon and K. W. Bradley, "Influence of Application Timings and Sublethal Rates of Synthetic Auxin Herbicides on Soybean," Weed Technology, vol. 28, no. 3, pp. 454-464, 2014.

[22] L. Thompson Jr. and D. B. Egli, "Evaluation of seedling offspring of soybeans treated with 2,4-D, 2,4-DB, and dicamba," Weed Science, vol. 21, pp. 141-144, 1973.

[23] J. F. Egan, K. M. Barlow, and D. A. Mortensen, "A meta-analysis on the effects of 2,4-D and dicamba drift on soybean and cotton," Weed Science, vol. 62, no. 1, pp. 193-206, 2014.

[24] M. R. Miller and J. K. Norsworthy, "Influence of herbicide rate, application volume, and adjuvant use on efficacy of Rinskor ${ }^{T M}$ active," in Arkansas Agriculture Experiment Station Research, Wells Rice Research Studies 2015, pp. 196-2000, 2016.

[25] J. K. Norsworthy, S. M. Ward, D. R. Shaw et al., "Reducing the risks of herbicide resistance: best management practices and recommendations," Weed Science, vol. 60, no. 1, pp. 31-62, 2012. 


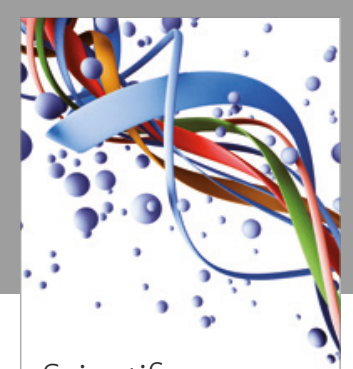

Scientifica
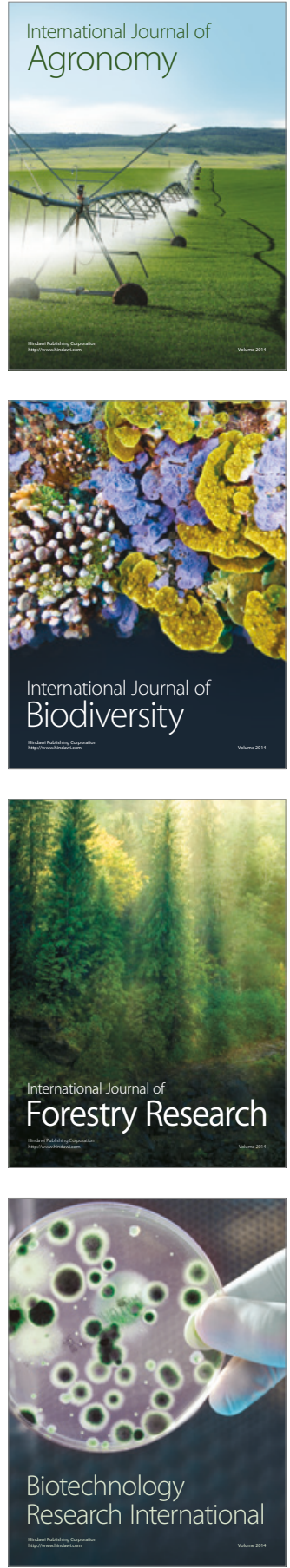
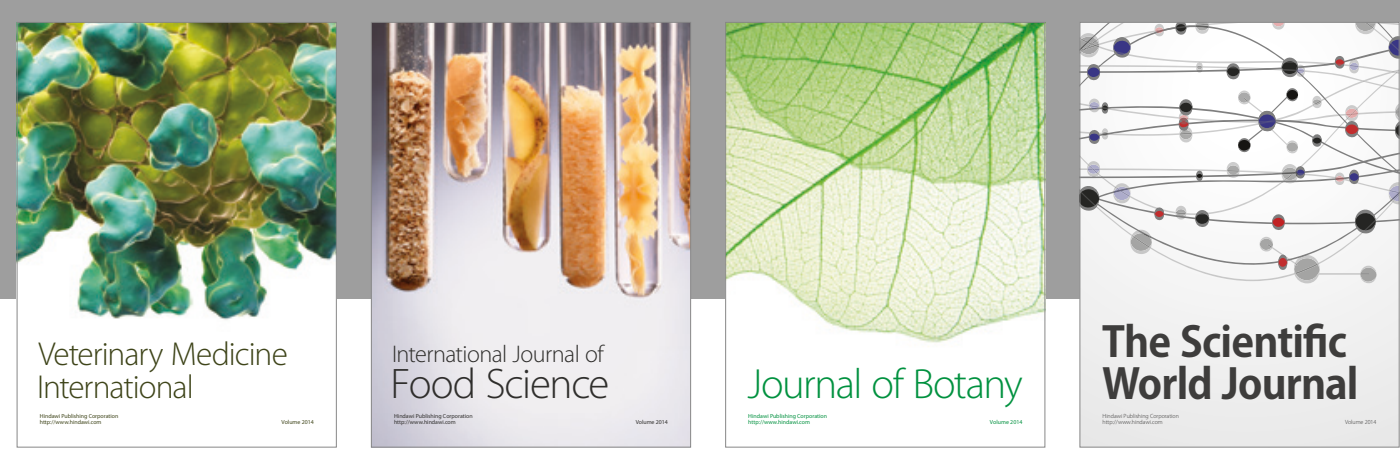

The Scientific

\section{World Journal}

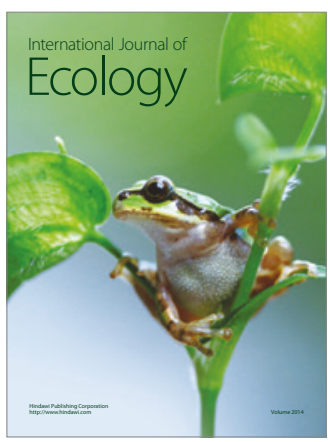

\section{Hindawi}

Submit your manuscripts at

https://www.hindawi.com
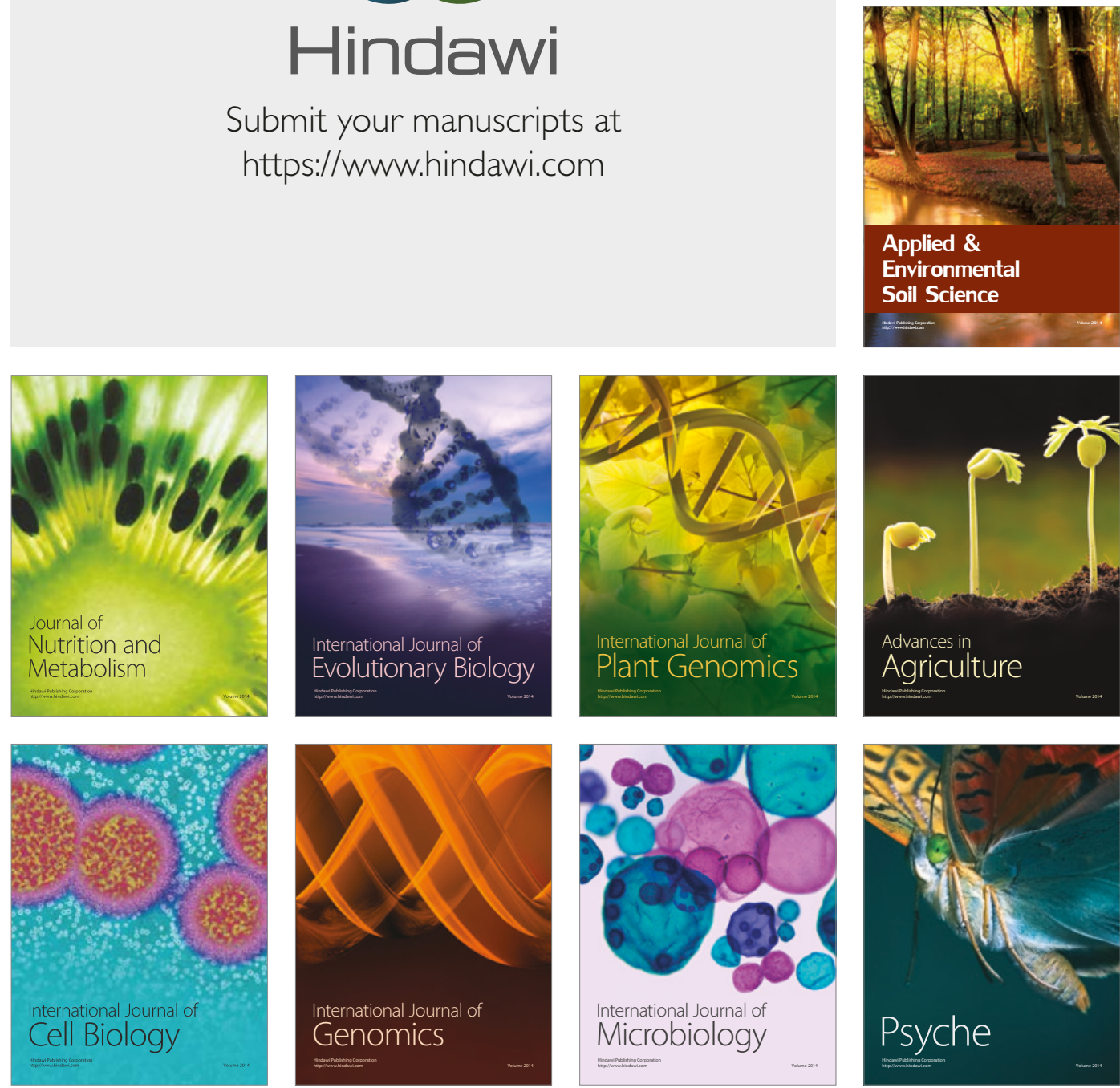

hternational Journal of Microbiology
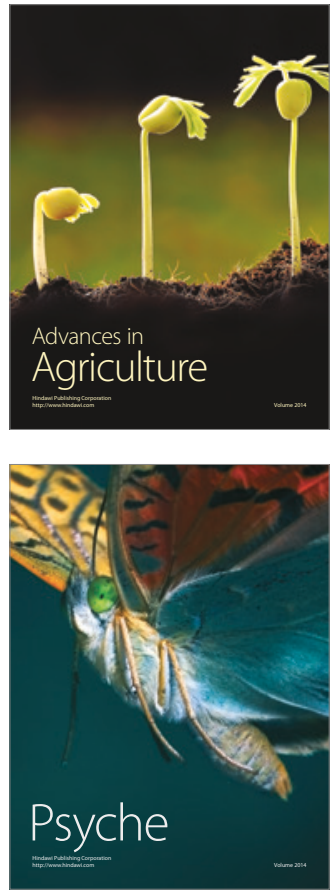